\title{
Hormonal changes around oestrus of farmed fallow deer, Dama dama
}

\author{
G. W. Asher, G. K. Barrell* and A. J. Peterson \\ Ruakura Animal Research Station, Ministry of Agriculture \& Fisheries, Private Bag, Hamilton, \\ New Zealand and *Animal Sciences Group, Lincoln College, Canterbury, New Zealand
}

\begin{abstract}
Summary. Concentrations of $\mathrm{LH}$, progesterone, oestradiol-17 $\beta$ and androstenedione were measured in serum from blood samples collected from 6 fallow does every hour for $46 \mathrm{~h}$ during a spontaneous oestrus. Four does had similar serum hormone profiles, with a pronounced preovulatory LH surge $(\sim 20 \mathrm{ng} / \mathrm{ml})$ occurring within $4 \mathrm{~h}$ of the onset of oestrus, a small elevation (from 0.1 to $0.3 \mathrm{ng} / \mathrm{ml}$ ) of progesterone at the onset of oestrus, a gradual but non-significant increase (up to $25 \mathrm{pg} / \mathrm{ml}$ ) of oestradiol- $17 \beta$ and a marked 2-fold increase of serum androstenedione concentrations occurring immediately at the onset of oestrus. The remaining 2 does showed pronounced increases in serum progesterone concentrations at the onset of oestrus and a reduction in the initial LH surge. One of these does exhibited a second preovulatory LH surge within the sampling period.
\end{abstract}

\section{Introduction}

The temporal relationships of pituitary and ovarian hormones around oestrus have been well documented for domestic ruminants such as sheep (Baird, Swanston \& McNeilly, 1981), cattle (Walters \& Schallenberger, 1984) and goats (Mori \& Kano, 1984). Hormonal secretion profiles obtained from blood samples collected at daily intervals during the oestrous cycles of roe deer (Schams, Barth \& Karg, 1980), white-tailed deer (McKeown \& Sadleir, 1978; Plotka, Seal, Verme \& Ozoga, 1980), red deer (Kelly, McNatty \& Moore, 1985) and fallow deer (Asher, 1985) have provided some insight into the endocrine control of oestrus and ovulation in cervid species. However, the frequency of blood sampling in these studies was insufficient to determine fully the temporal relationships of the hormones investigated. Furthermore, there have been no previous investigations on blood androgen concentrations during the oestrous cycle of the deer species mentioned above.

Fallow does are seasonally polyoestrous (Cowan, 1965; Armstrong, Chaplin, Chapman \& Smith, 1969; Chapman \& Chapman, 1969, 1975; Baker, 1973; Asher, 1985). On New Zealand farms, first oestrus of the breeding season occurs in autumn, towards the end of April, and is synchronized within a 12-day period. In the absence of conception, does will exhibit a second oestrus 21 days later (Asher, 1985). So far the temporal relationships of pituitary and ovarian hormones involved in these events have not been investigated. This study describes changes in serum concentrations of progesterone, oestradiol-17 $\beta$, androstenedione and luteinizing hormone (LH) during the oestrous or preovulatory period of fallow does.

\section{Materials and Methods}

Animals and management. Six nonparous, 3-year-old fallow does, run continuously with a vasectomized buck during the previous year's breeding season (Asher, 1985), had their first oestrus of 1984 
artificially synchronized by timed withdrawal of a source of exogenous progesterone. A single silicone elastomer (polydimethylsiloxane) device impregnated with $0.5 \mathrm{~g}$ progesterone (CIDR [Controlled Internal Drug Release]: AHI Plastic Moulding Co., Hamilton, NZ) was inserted intravaginally into each doe on 16 April and removed 9 days later. After CIDR removal the does were run with a tame vasectomized buck for the duration of the breeding season.

The deer were contained in high-fenced paddocks within 150 metres of an enclosed observation platform. They were grazed on ryegrass-clover pastures and offered supplements of meadow hay and whole-kernel maize.

Detection of oestrus. Two days before CIDR removal, the hair of each doe's hindquarters was bleached with hydrogen peroxide solution to aid detection of crayon mating marks. The vasectomized buck was fitted with a ram mating harness (Fergus: Merck, Sharp \& Dohme NZ Ltd, Auckland, NZ) containing a red crayon that was replaced every 2 nd or 3 rd day. After CIDR removal, the does were checked for mating marks or signs of overt oestrous behaviour at least every hour during daylight hours from 25 April to 28 April inclusive. Thereafter until 17 May, twice daily observations were made to detect premature occurrence of the subsequent oestrus. Spontaneous second oestrus, which was predicted to occur 21 days after induced oestrus (Asher, 1985), was detected by hourly observations of the does during a $46-\mathrm{h}$ intensive blood sampling regimen between Days 20 and 22 inclusive from induced oestrus.

Blood sampling. (a) Every 2 days from the day of CIDR insertion to 17 May (Day 20 of the oestrous cycle), the does were mustered into a covered handling shed, individually restrained in a cradle device and blood $(\sim 10 \mathrm{ml})$ was withdrawn into Vacutainers by jugular venepuncture. Following the subsequent period of intensive hourly blood sampling (see below), the does were blood sampled every 3 days until 10 October (cessation of cyclic ovarian activity).

(b) From $06: 00 \mathrm{~h}$ on 17 May until 04:00 h on 19 May inclusive $(46 \mathrm{~h})$ the does were individually restrained in the cradle and blood samples were taken every hour. Samples $(\sim 10 \mathrm{ml})$ were withdrawn from the left external jugular vein into Vacutainers, with each puncture site (21-gauge needle) placed immediately below the previous site. Skin covering the left jugular vein had been shaved previously and was cleaned with antiseptic solution after each sampling. After each sampling, which lasted 5-6 min, the does were reunited with the buck in a small paddock adjacent to the yards.

Blood samples were chilled to $\sim 5^{\circ} \mathrm{C}$ immediately after collection and then centrifuged at $1000 \mathrm{~g}$ for $30 \mathrm{~min}$ within $2 \mathrm{~h}$ from collection. The serum was transferred to glass vials and stored at $-10^{\circ} \mathrm{C}$ until assayed.

Hormone assays. Of the serum samples, 650 were assayed for progesterone and 280 were also analysed for concentrations of oestradiol-17ß, androstenedione and luteinizing hormone, using conventional radioimmunoassay techniques.

Progesterone was measured by a radioimmunoassay similar to that described by Fairclough, Hunter \& Welch (1975) and has been validated previously for fallow deer serum (Asher, 1985). The progesterone antiserum (Ruakura $R_{2}$ ) was raised in a rabbit against progesterone-11-BSA conjugate and used at a final dilution of 1:3000. The major cross-reaction with other steroids which were tested in the assay was $1.5 \%$ with cholesterol, while those for androstenedione, testosterone, oestradiol and other progestagens tested were all $<0.01 \%$. The sensitivity of the standard curve was $0.03 \mathrm{ng}$ and the intra- and inter-assay coefficients of variation were $6.7 \%$ and $<12 \%$ respectively.

Oestradiol $-17 \beta$ was assayed by a method similar to that described by Peterson, Fairclough \& Smith (1975) that has been validated for red deer serum (Kelly, McNatty, Moore, Ross \& Gibb, 1982). As with serum from other species, the ether extract of fallow deer serum $(1.0 \mathrm{ml})$ was routinely subjected to Sephadex $\mathrm{LH}-20$ gel filtration to remove material which interfered in the assay when performed without filtration. The antiserum (Wallaceville-27) used in the assay was raised in an ovariectomized ewe against oestradiol-6-(O-carboxymethyl)-oxime-BSA conjugate 
and was used at a final dilution of 1:48 000. The major cross-reactions of other steroids in the assay were: oestrone $7 \cdot 3 \%$, oestriol $1.4 \%$, oestradiol- $17 \alpha 1 \cdot 4 \%$ and androstenedione $0.015 \%$. All samples from an individual were included in a single assay. Low (charcoal-stripped serum from a castrated buck), medium (the same with addition of $50 \mathrm{pg}$ oestradiol $-17 \beta / \mathrm{ml})$ and high $(200 \mathrm{pg}$ oestradiol- $17 \beta / \mathrm{ml}$ ) control samples were included in each assay. The inter-assay coefficients of variation were $7 \cdot 8 \%$ for the medium control $(n=6$, mean $=45.7 \mathrm{pg} / \mathrm{ml})$ and $4.5 \%$ for the high control $(n=6$, mean $=181 \cdot 7 \mathrm{pg} / \mathrm{ml})$. The intra-assay coefficient of variation, calculated from 10 serum samples assayed in duplicate in 5 assays, was $8.7 \%$. The recovery ( \pm s.d.) of oestradiol-17 $\beta$ from medium and high control samples (6 determinations) was $91 \cdot 4 \pm 7 \cdot 2 \%$ and $90.9 \pm 4 \cdot 1 \%$ respectively. Extraction efficiency for radioactive oestradiol-17 $\beta$ added to doe serum (10 determinations) was $97 \cdot 0 \pm 3 \cdot 1 \%$ and the sensitivity of the standard curve was $5 \mathrm{pg}$.

Androstenedione was assayed by a method similar to that described by Peterson et al. (1978) but omitting the chromatographic step used to separate androgens. The antiserum used in the assay was raised in an ovariectomized ewe against androstenedione- $6 \beta$-succinyl-BSA conjugate and was used at a final dilution of 1:4500. The major cross-reaction with other steroids which were tested in the assay was $0 \cdot 2 \%$ with testosterone. All samples from an individual were included in a single assay. A control sample (entire buck serum) was included in each assay. The inter-assay coefficient of variation was $17.4 \%(n=7$; mean $=395 \mathrm{pg} / \mathrm{ml})$ and the intra-assay coefficient of variation, calculated from 50 duplicates randomly selected across all assays, was $12 \cdot 0 \%$. The recovery ( \pm s.d.) of androstenedione added to charcoal-stripped serum from a castrated buck (10 determinations) was $74.0 \pm 3.0 \%$ at $50 \mathrm{pg} / \mathrm{ml}$ and $79.8 \pm 5.7 \%$ at $200 \mathrm{pg} / \mathrm{ml}$. Extraction efficency for radioactive androstenedione added to doe serum (10 determinations) was $81 \cdot 1 \pm 3.4 \%$ and the sensitivity of the standard curve was $5 \mathrm{pg}$.

Luteinizing hormone $(\mathrm{LH})$ concentration in fallow deer serum was determined using a heterologous radioimmunoassay procedure described for sheep plasma by Scaramuzzi, Caldwell \& Moor (1970) and red deer plasma by Kelly et al. (1982). The ovine pituitary LH preparations used for standards and iodinated tracer were NIH-LH-S11. The LH antibody, which had been raised in a rabbit also using NIH-LH-S11 as the antigen, was used in the assay at a final dilution of 1:200 000 . Cross-reactivity with other proteins occurred to the following extent: NIH-P-S12 0.09\%, NIHTSH-S $82.4 \%$, NIH-GH-S1 $10 \cdot 4 \%$, NIH-FSH-S100.4\%, NIH-P-B50.16\%, ovine ACTH (SchwarzMann) $<0.01 \%$, ovine serum albumin $<0.01 \%$, bovine serum albumin $<0.01 \%$, bovine TSH (Schwarz-Mann) $<0.01 \%$, human prolactin $\left(\mathrm{VLS}_{4}\right)<0.01 \%$ and human FSH $<0.01 \%$ (after Kelly et al., 1982). No fallow deer pituitary preparations or standards were available for testing in the above assay system. Nevertheless, serial dilutions of pooled serum samples from oestrous does with high concentrations of immunoreactive LH gave inhibition curves parallel to those generated for NIH-LH-S11 in buffer (Fig. 1). All samples were included in a single assay and the intraassay coefficient of variation, calculated from 100 duplicates selected at random, was $5.8 \%$. The sensitivity of the standard curve was $0.05 \mathrm{ng} \mathrm{NIH-LH-S11/tube.}$

Statistical procedures. The results for all hormones are expressed as means \pm 1 s.e.m. Differences between specific pairs of means were tested using Student's $t$ test.

\section{Results}

\section{Occurrence of oestrus}

The onset of the initial, induced oestrus was detected for all 6 does between 48 and $56 \mathrm{~h}$ after CIDR removal. A second oestrus was therefore predicted to occur 21 days later, on 18 May. During the period of hourly blood sampling spanning this date, the 6 does returned to oestrus within a $19 \mathrm{~h}$ period. A third oestrus was detected in all does $21-22$ days after the second oestrus, indicating that ovulation had occurred around the time of intensive blood sampling. 


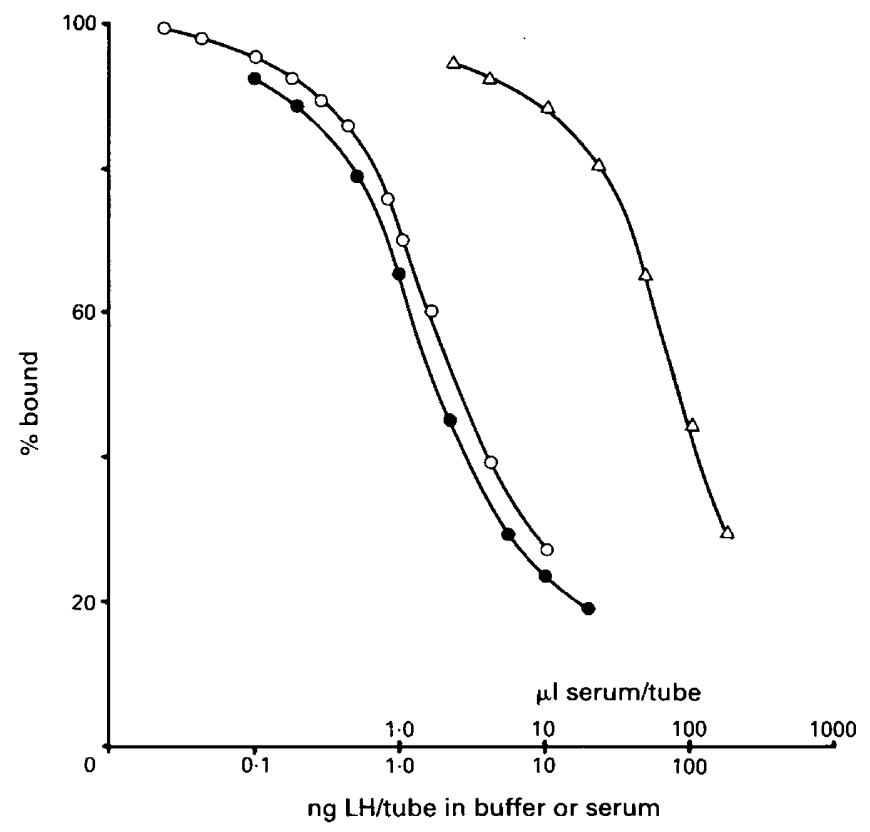

Fig. 1. Inhibition curves of pooled serum from oestrous fallow does $(\Delta)$, NIH-LH-S11 in buffer $(\bigcirc)$, and in serum from an entire fallow buck $(\odot)$. Radioactivity in all cases is expressed as the percentage of ${ }^{125} \mathrm{I}$-labelled $\mathrm{LH}$ found in the buffer control tubes.

\section{Evidence of normal oestrous cycles}

Individual doe progesterone profiles over the entire breeding season, starting from the day of CIDR insertion, are presented in Fig. 2. In each doe, the first elevation of serum progesterone ( 9 days) represents exogenously derived progesterone. Subsequent cycles of serum progesterone concentration represent apparently normal oestrous cycles of 21-23 days duration. None of the does exhibited unusually short or long oestrous cycles.

\section{Hormone changes around spontaneous oestrus}

The mean serum hormone concentrations, normalized around the onset of oestrus, of 4 does exhibiting similar individual profiles, are presented in Fig. 3. Mean serum LH values were basal ( $\sim 2 \mathrm{ng} / \mathrm{ml}$ ) until about $1 \mathrm{~h}$ before the onset of oestrus, and then they began to increase progressively, culminating in peak levels $(\sim 20 \mathrm{ng} / \mathrm{ml}) 3 \mathrm{~h}$ after the onset of oestrus. These values remained elevated for a further $4 \mathrm{~h}$ and thereafter progressively declined to the original basal levels before oestrus $(\sim 2 \mathrm{ng} / \mathrm{ml})$ by $13-14 \mathrm{~h}$ after the onset of oestrus.

Mean serum progesterone concentrations declined from initial values of $0.2-0.3 \mathrm{ng} / \mathrm{ml}$ to $\sim 0.1 \mathrm{ng} / \mathrm{ml} 4 \mathrm{~h}$ before the onset of oestrus. Thereafter, there was an increase of mean concentrations to $\sim 0.25 \mathrm{ng} / \mathrm{ml}$ by $1 \mathrm{~h}$ and after the onset of oestrus, followed by a further decline to mean levels of $\sim 0 \cdot 1 \mathrm{ng} / \mathrm{ml}$ over the next $8 \mathrm{~h}$.

Mean serum oestradiol-17 $\beta$ values increased from 11 to $25 \mathrm{pg} / \mathrm{ml}$ up to, and $2 \mathrm{~h}$ beyond, the onset of oestrus; thereafter they declined to $\sim 15 \mathrm{pg} / \mathrm{ml}$. However, at no stage during the intensive blood sampling period was there a significant difference between hourly mean serum oestradiol-17\% values $(P>0 \cdot 1)$ due to the wide variation in concentrations between individual does and between consecutive blood samples. 

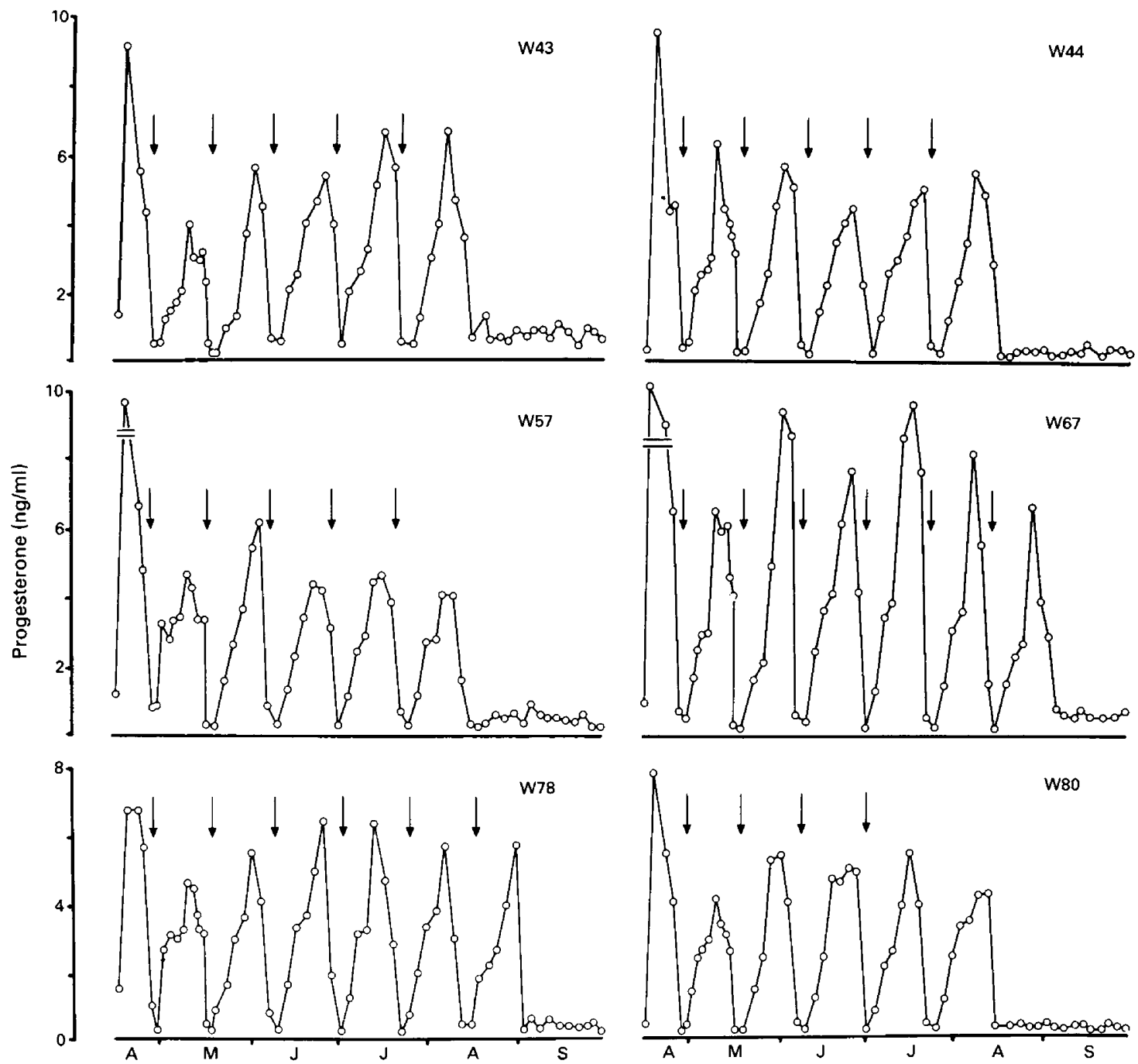

Fig. 2. Individual serum progesterone profiles (2-3-day blood sampling) of the 6 fallow does during the 1984 breeding season, recorded from the day of CIDR insertion until cessation of ovulatory activity. The first progesterone elevation cycle ( 9 days) represents exogenous progesterone derived from the CIDRs. Arrows indicate the occurrence of oestrus.

Mean serum androstenedione concentrations exhibited a pronounced elevation from basal $(110-130 \mathrm{pg} / \mathrm{ml})$ to peak $(\sim 230 \mathrm{pg} / \mathrm{ml})$ values at the onset of oestrus. Peak mean levels were maintained for $6 \mathrm{~h}$, thereafter they declined to the original mean values before oestrus over the next $6 \mathrm{~h}$. Serum androstenedione concentrations in consecutive blood samples from individual does clearly showed marked fluctuations before and after the major elevation over the oestrous period.

\section{Unusual hormone changes over oestrus}

Two does in the trial exhibited serum hormone profiles that were markedly different from those described above. Doe W44 (Fig. 4) clearly had two surges of serum LH, the peak values of the first $(\sim 12 \mathrm{ng} / \mathrm{ml}$ ) being of lower magnitude than those of the second ( $\sim 20 \mathrm{ng} / \mathrm{ml})$, which occurred about $18 \mathrm{~h}$ later. The first serum LH surge was concomitant with a marked elevation in serum 

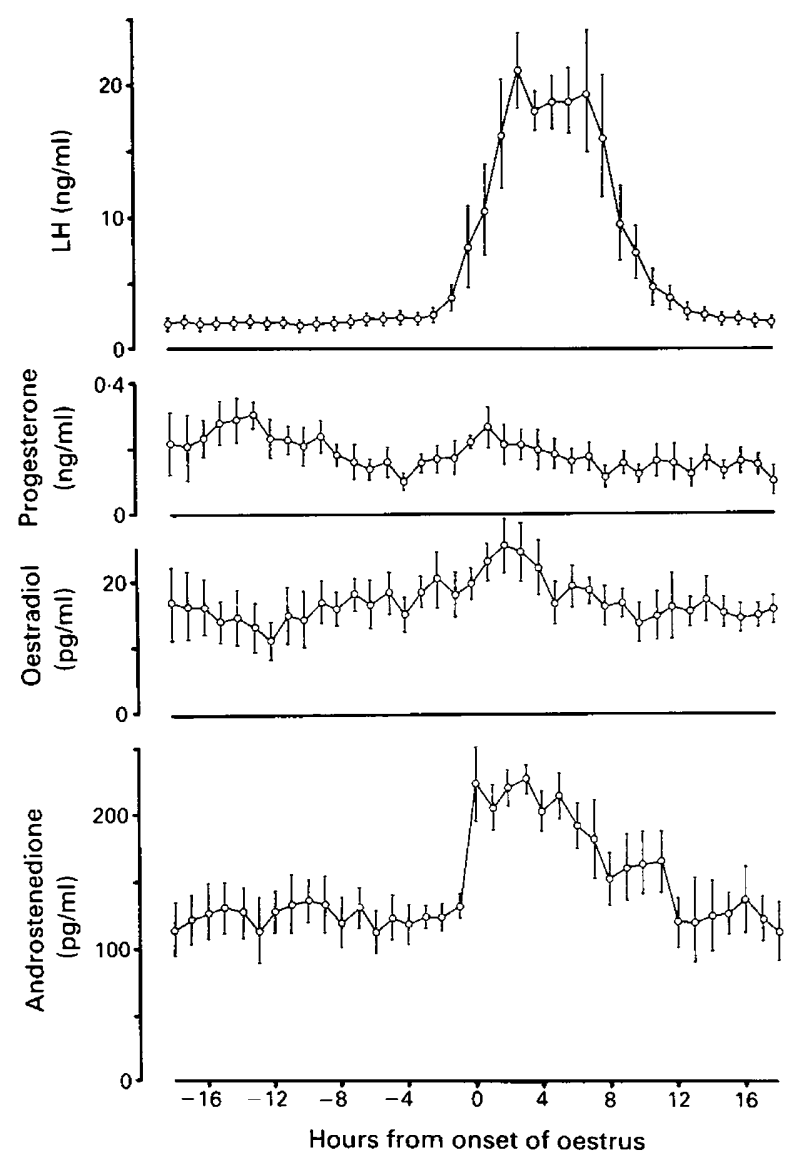

Fig. 3. Mean serum concentrations ( \pm s.e.m.) of $\mathrm{LH}$, progesterone, oestradiol-17 $\beta$ and androstenedione, recorded hourly about oestrus (Hour 0 ) from 4 fallow does.

androstenedione concentrations and a small (up to $0.5 \mathrm{ng} / \mathrm{ml}$ ) but pronounced rise in serum progesterone concentrations, at the onset of oestrus. The second serum LH surge in Doe W44 was not associated with elevations of either serum androstenedione or progesterone, and serum oestradiol$17 \beta$ concentrations appeared to be actually declining at this stage. However, there is an indication that serum androstenedione concentrations were increasing towards the end of the hourly blood sampling period, when serum LH values were declining.

The hormonal profile for Doe W57 (Fig. 4) was notably different from that of any other doe in the study. There was a major surge in serum progesterone concentrations $(>5.0 \mathrm{ng} / \mathrm{ml})$, concomitant with that of androstenedione, at the onset of oestrus. Both of these hormone elevations were short-lived $(3-4 \mathrm{~h}$ ) and were followed by a modest serum $\mathrm{LH}$ surge (up to $\sim 9 \mathrm{ng} / \mathrm{ml}$ ). Towards the end of the hourly blood sampling period, serum concentrations of androstenedione and progesterone appeared to increase as serum $\mathrm{LH}$ values were decreasing.

\section{Discussion}

All 6 fallow does in this study exhibited a spontaneous oestrus within the predetermined period of intensive hourly blood sampling. Several factors contributed to this success. First, the CIDR treat- 


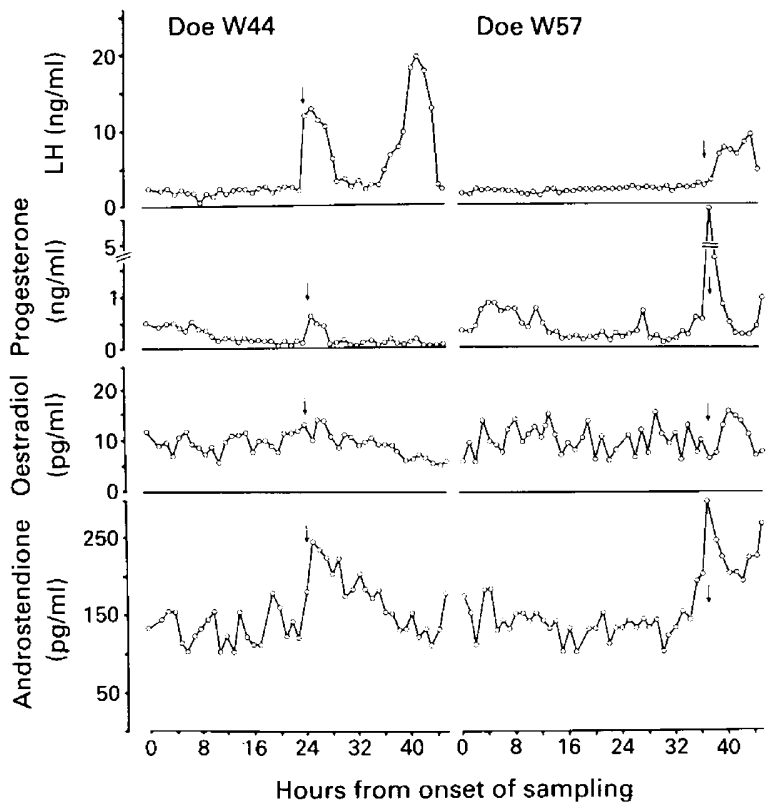

Fig. 4. Individual fallow doe serum profiles, from hourly blood sampling, of $\mathrm{LH}$, progesterone, oestradiol-17 $\beta$ and androstenedione concentrations over the 46-h period spanning oestrus of 2 does, W44 and W57, that exhibited hormonal profiles that were markedly different from those represented in Fig. 3. Arrows indicate the onset of oestrus.

ment was highly effective and synchronized oestrus within an 8-h period. Secondly, as has been observed previously for fallow does (Asher, 1985), the length of the first oestrous cycle was of remarkable uniformity between does. This resulted in the second oestrus being exhibited within a 19-h period.

Four of the does had hormone profiles that were essentially similar and these presumably represent normal endocrine relationships throughout oestrus in fallow does. However, in the absence of remote blood sampling methodology which could reduce stress to animals during such studies, the acceptance that the hormone profiles recorded here represent 'normal' changes needs to be treated with some degree of caution. Furthermore, the fact that 2 of the does in this study exhibited serum hormone profiles that were different perhaps implicates stress as having some influence in producing hormonal artefacts.

For the 4 does that exhibited similar serum hormone profiles there is little doubt that the surge of serum LH concentrations immediately after the onset of oestrus represented the 'preovulatory' LH surge, as has been recorded during the peri-oestrous period of other domestic livestock. Similarly, endocrine data from daily blood sampling during the oestrous cycle of roe deer (Schams et al., 1980), white-tailed deer (Plotka et al., 1980) and red deer (Kelly et al., 1985) occasionally showed $\mathrm{LH}$ peaks $(>10 \mathrm{ng} / \mathrm{ml}$ ) on, or near, the day of oestrus. Failure to observe these LH peaks in some individuals probably reflects the wide interval between samples because, on the basis of the duration of the preovulatory LH surge observed in this study on fallow deer and reported in the literature for other domestic ruminants, the preovulatory LH surge in many cervid species is likely to be $<24 \mathrm{~h}$ in duration.

Although basal serum LH concentrations from individual doe profiles showed occasional short-term fluctuations between 1.0 and $2.5 \mathrm{ng} / \mathrm{ml}$, the hourly blood sampling regimen did not allow precise delineation of $\mathrm{LH}$ pulses in fallow deer. 
Declining serum progesterone concentrations during the last week of the first oestrous cycle, which are indicative of spontaneous luteolysis, were recorded from all 4 of these does. The increase in serum progesterone concentration during the earlier stages of oestrus, while not a major surge, does raise questions about its source and physiological significance. Wheeler, Baird, Land \& Scaramuzzi (1975) reported an increase in plasma progesterone concentrations in the ovarian vein of sheep during the preovulatory LH surge. Likewise, an increase in vena caval progesterone concentrations, concomitant with the LH surge, has been reported for cattle (Walters \& Schallenberger, 1984). As the preovulatory rise in serum progestrone concentrations in fallow deer appeared to be related to the onset of oestrus rather than the LH surge, it is possible that the event is not analogous to that described for sheep and cattle.

Because of the marked fluctuations throughout the period of hourly blood sampling, a specific elevation of serum oestradiol-17 $\beta$ concentrations coincident with the start of the preovulatory LH surge and the onset of oestrus was not always apparent. Mean serum oestradiol-17 $\beta$ concentrations did tend to increase up to, and slightly beyond, the start of these events, although the elevation was not as pronounced as that demonstrated for other domestic ruminants (e.g. Yuthasastrakosol, Palmer \& Howland, 1975; Smith, Fairclough, Payne \& Peterson, 1975). In white-tailed deer, although plasma oestradiol-17 $\beta$ concentrations increased 3-4 days before oestrus, mean values were not significantly different at any stage during the oestrous cycle (Plotka et al., 1980). Plotka et al. (1980) suggested that changes in the oestradiol-17ß:progesterone ratio over the preovulatory period would explain the temporal relationship of these two hormones during oestrus. This ratio, however, is more a reflection of declining plasma progesterone concentrations than of any changes in plasma oestradiol-17 $\beta$ values. In contrast to white-tailed deer, red deer exhibited very high concentrations (up to $\sim 200 \mathrm{pg} / \mathrm{ml}$ ) of plasma oestradiol-17 $\beta$ during the oestrous cycle (Kelly et al., 1985), although there were no obvious peaks confined to within 1 day of oestrus. It therefore seems that, for at least three species of deer, the role of oestradiol- $17 \beta$ in stimulating the preovulatory surge of $\mathrm{LH}$ and the expression of oestrous behaviour is equivocal.

One of the most interesting features of the hormone profiles of the fallow does in this study is the marked elevation of serum androstenedione concentrations which occurred at the onset of oestrus. This is the first report of androstenedione concentrations around oestrus in any species of deer. The close temporal relationship between the initiation of the preovulatory LH surge and the sudden elevation of serum androstenedione concentrations strongly suggests a causal association, whereby LH is stimulating the release of androstenedione. Although a role for androgens in the expression of oestrus in sheep and cattle is generally discounted, it is tempting to link the elevation of serum androstenedione values to the occurrence of oestrous behaviour in fallow deer. This is supported by the fact that serum androstenedione concentrations remained elevated for up to $12 \mathrm{~h}$ after the onset of oestrus. Although oestrous behaviour is terminated at copulation, within an hour of the onset of oestrus, the observed duration of oestrus of a doe that was not promptly mated was at least $8 \mathrm{~h}$ (G. W. Asher, unpublished data).

Two of the deer in the present study (Does W44 and W59) exhibited hormone profiles that were clearly different from those of the other does. A common feature of the profiles of these 2 does was the elevation of serum progesterone concentrations at the onset of oestrus, which was particularly pronounced for Doe W57. These elevations were possibly analogous with the minor elevation of mean serum progesterone values observed around the onset of oestrus of the other 4 does. These increases in serum progesterone concentrations probably account for the anomalies observed for serum values of other hormones, e.g. the suppression of LH secretion, because the preovulatory LH surges were of lower magnitude and of shorter duration than those observed for the other does. Furthermore, concomitant with the early decline of the LH surge, there appeared to be a premature decline in serum androstenedione concentrations which had peaked previously at the onset of oestrus, again suggesting a positive effect of LH on androstenedione secretion. However, these two does definitely ovulated after oestrus, as indicated by their return to oestrus 21-22 days later. In 
Doe W44, this ovulation was probably in response to a second preovulatory LH surge that was observed to occur in the apparent absence of a concomitant elevation of serum progesterone. It is likely, therefore, that a second preovulatory LH surge also occurred in Doe W57 sometime after the cessation of hourly blood sampling.

The source of the elevated serum progesterone concentrations at the onset of oestrus of these 2 does is unknown. Kelly et al. (1985) argued that the erratic fluctuations of plasma progesterone concentrations observed on the day of oestrus in red deer may have been due to the presence of a functional 'accessory' corpus luteum which had failed to regress completely. Accessory corpora lutea do not occur in fallow deer (Armstrong et al., 1969; Chapman \& Chapman, 1969, 1975; Baker, 1973) and therefore could not be a source of serum progesterone at the onset of oestrus. Daily blood sampling during the oestrous cycle of these and other fallow does in 1983 did not reveal any high or erratic serum progesterone concentrations at or near the day of oestrus (Asher, 1985), further indicating the absence of accessory corpora lutea in this species.

While it is possible that the erratic fluctuations of plasma progesterone concentrations observed in cyclic red deer hinds (Kelly et al., 1985) are due to adrenal secretion occurring as a direct consequence of handling stress, as has been indicated for white-tailed deer (Plotka et al., 1983), this argument is not applicable to fallow deer, as short-term elevations of serum progesterone occurred only at the onset of oestrus. However, this event in some fallow deer may possibly be explained by adrenal secretion of the hormone in response to the stimulus of oestrous behaviour.

We thank Dr J. L. Adam and Dr K. L. McMillan (Ruakura) for encouragement and advice during this study; G. A. J. Parton for performing the LH assay; Dr K. P. McNatty (Wallaceville Animal Research Centre, Upper Hutt) for providing assay facilities (oestradiol-17 $\beta$ ); and $\mathbf{M}$. Langridge, K. Hargreaves, H. Humble, and other staff of the Ruakura Deer Unit for assistance in animal management and blood sampling.

\section{References}

Armstrong, N., Chaplin, R.E., Chapman, D.I. \& Smith, B. (1969) Observations on the reproduction of female wild and park fallow deer (Dama dama) in southern England. J. Zool., Lond. 158, 27-37.

Asher, G.W. (1985) Oestrous cycle and breeding season of farmed fallow deer, Dama dama. J. Reprod. Fert. $75,521-529$.

Baird, D.T., Swanston, I.A. \& McNeilly, A.S. (1981) Relationship between LH, FSH and prolactin concentration and secretion of androgens and estrogens by the preovulatory follicle in the ewe. Biol. Reprod. 24, 1013-1025.

Baker, K. (1973) Reproductive biology of fallow deer (Dama dama) in the Blue Mountains of New Zealand. M.Sc. thesis, University of Otago.

Chapman, D.I. \& Chapman, N. (1969) Observations on the biology of fallow deer (Dama dama) in Epping Forest, Essex, England. Biological Conservation 2, 55-62.

Chapman, D.I. \& Chapman, N. (1975) Fallow deer: their History, Distribution and Biology. Terence Dalton Ltd, Lavenham.

Cowan, I. McT. (1965) Life and times of the coast black-tailed deer. In The Deer of North America, pp. 523-617. Ed. W. P. Taylor. Stackpole Co., Washington, D.C.
Fairclough, R.J., Hunter, J.T. \& Welch, R.A.S. (1975) Peripheral plasma progesterone and utero-ovarian prostaglandin $\mathrm{F}_{2 \alpha}$ concentrations in the cow around parturition. Prostaglandins 9,901-914.

Kelly, R.W., McNatty, K.P., Moore, G.H., Ross, D. \& Gibb, M. (1982) Plasma concentrations of LH, prolactin, oestradiol and progesterone in female red deer (Cervus elaphus) during pregnancy. J. Reprod. Fert. 64, 475-483.

Kelly, R.W., McNatty, K.P. \& Moore, G.H. (1985) Hormonal changes about oestrus in female red deer. In Biology of Deer Production, pp. 181-184. Eds P. F. Fennessy \& K. R. Drew. The Royal Society of NZ, Bulletin 22, Wellington.

McKeown, B.A. \& Sadleir, R.M.F.S. (1978) Changes in gonadotrophin and ovarian hormone levels during the estrous cycle of black-tailed deer (Odocoileus hemionus columbianus). Biochem. exp. Biol. 14, 215-220.

Mori, Y. \& Kano, Y. (1984) Changes in plasma concentrations of $\mathrm{LH}$, progesterone and oestradiol in relation to the occurrence of luteolysis, oestrus and time of ovulation in the Shiba goat. J. Reprod. Fert. 72, 223-230.

Peterson, A.J., Fairclough, R.J. \& Smith, J.F. (1975) Radioimmunoassay of estradiol- $17 \beta$ in bovine per- 
ipheral plasma with and without chromatography. Steroids 25, 487-496.

Peterson, A.J., Fairclough, R.J. \& Smith, J.F. (1978) Radioimmunoassay of androstenedione and testosterone in cow plasma at the time of luteolysis and oestrus. J. Reprod. Fert. 52, 127-129.

Plotka, E.D., Seal, U.S., Verme, L.J. \& Ozoga, J.J. (1980) Reproductive steroids in deer. III. Luteinizing hormone, estradiol and progesterone around estrus. Biol. Reprod. 22, 576-581.

Plotka, E.D., Seal, U.S., Verme, L.J. \& Ozoga, J.J. (1983) The adrenal gland in white-tailed deer: a significant source of progesterone. J. Wildl. Mgmt 47, $38-44$.

Scaramuzxi, R.J., Caldwell, B.V. \& Moor, R.M. (1970) Radioimmunoassay of $\mathrm{LH}$ and estrogen during the estrous cycle of the ewe. Biol. Reprod. 3, 110-119.

Schams, D., Barth, D. \& Karg, H. (1980) LH, FSH and progesterone concentrations in peripheral plasma of the female roe deer (Capreolus capreolus) during the rutting season. J. Reprod. Fert. 60, 109-114.
Smith, J.F., Fairclough, R.J., Payne, E. \& Peterson, A.J. (1975) Plasma hormone levels in the cow. (1) Changes in progesterone and oestrogen during the normal oestrous cycle. N.Z. $J l$ agric. Res. 18, 123-129.

Walters, D.L. \& Schallenberger, E. (1984) Pulsatile secretion of gonadotrophins, ovarian steroids and ovarian oxytocin during the periovulatory phase of the oestrous cycle in the cow. J. Reprod. Fert. 71, 503-512.

Wheeler, A.G., Baird, D.T., Land, R.B. \& Scaramuzzi, R.J. (1975) Increased secretion of progesterone from the ovary of the ewe during the preovulatory period. J. Reprod. Fert. 45, 519-522.

Yuthasastrakosol, P., Palmer, W.M. \& Howland, B.E. (1975) Luteinizing hormone, oestrogen and progesterone levels in peripheral serum of anoestrus and cyclic ewes as determined by radioimmunoassay. $J$. Reprod. Fert. 43, 57-65.

Received 20 February 1986 